Georgetown University Institutional Repository

http://www.library.georgetown.edu/digitalgeorgetown

The author made this article openly available online. Please tell us how this access affects you. Your story matters.

Shore, Daniel. “WWJD? The Geneology of Syntatic Form." Critical Inquiry 37.1 (2010): $1-25$.

Collection Permanent Link: http://hdl.handle.net/10822/1041457

(C) 2010 The University of Chicago Press

This is the published version of an article published by The University of Chicago Press in Critical Inquiry, Autumn, 2010

This material is made available online with the permission of the author, and in accordance with publisher policies. No further reproduction or distribution of this copy is permitted by electronic transmission or any other means. 


\title{
WWJD? The Genealogy of a Syntactic Form
}

\author{
Daniel Shore
}

Over the past fifteen years the letters WWJD? and the question they abbreviate, what would Jesus do? have become prominent features of American culture, appearing on book covers, buttons, bracelets, blue jeans, board games, bumper stickers, teddy bears, T-shirts, ties, key chains, coffee mugs, pencils, and even women's underwear. (This last item is truly a complex cultural artifact; is it worn by the devout or the derisive, to deter seducer or seducee, and by aesthetic or ethical deterrence?) In more recent years, the question has given rise to scores of spin-offs, devout and derisive alike. The "Who Would Jesus Vote For?" website, wwjv4.com, is a selfdescribed "progressive political blog that highlights the infringement of religion upon today's government." Those seeking a "Christian nutrition handbook" need look no further than What Would Jesus Eat? which bills itself as a "healthier, Bible-based eating program."' (Think water, bread, and lots of fish.) The Evangelical Environmental Network, a progressive evangelical group, launched the "What Would Jesus Drive?" ad campaign in 2002; now the question appears on bumpers across the nation. ${ }^{2}$

Parodic spin-offs of WWJD? sometimes retain the moral aims of the original. Antiwar protesters, for example, hold up signs that read "Who Would Jesus Bomb?" But another popular variety of spin-off, in which Jesus' name is replaced with another name (usually that of a popular athlete), is markedly less rich in satire and ethical intent. Few have received

1. www.amazon.com/Ultimate-Program-Eating-Feeling-Living/dp/product-description/ 0785265678 . This is from the publisher's description for Don Colbert, What Would Jesus Eat? (Nashville, 2002).

2. See Jay W. Richards, "What Would Jesus Drive?" National Review, 25 Sept. 2007, energy.nationalreview.com/articles/222272/what-would-jesus-drive/jay-w-richards

Critical Inquiry 37 (Autumn 2010)

(C) 2010 by The University of Chicago. 0093-1896/10/3701-0006 \$10.00. All rights reserved. 
moral guidance from asking themselves, what would Johnny Damon do? Or, what would Michael Jordan do?3 The question and its mutations have even begun to edge their way into academia. John D. Caputo, a notable scholar of deconstruction and proponent of theopoetics, published What Would Jesus Deconstruct? ${ }^{4}$ The 2008 Modern Language Association convention featured a panel entitled "WWWD? What Would Wharton Do? Edith Wharton and Politics."

For many Christians inside and outside of the evangelical community, WWJD? has become the ethical question par excellence. Like the Golden Rule, the categorical imperative, the principle of utility, or the veil of ignorance, it serves as a distinctive kind of moral deliberation. We might hypothesize that in the present day WWJD? is a more popular ethical guide than the systems offered by Immanuel Kant, J. S. Mill, or John Rawls (although perhaps not the Golden Rule). And while some Christians turn to the question in times of moral difficulty, others use it to direct every aspect of their daily lives. The question of what Jesus would do is, in one sense, an old one. It is part of the tradition of imitatio Christi, in which believers model their actions on the pattern set forth in the life of Jesus as described in the Gospels. But it is also, in another sense, very new-the most novel form of a practice some two millennia old.

The phrase what would Jesus do? is usually traced back to the late nineteenth century to a short novel by Charles Sheldon called In His Steps. ${ }^{5}$

3. Although see Brendan Vaughan, What Would MacGyver Do? True Stories of Improvised Genius in Everyday Life (New York, 2006); E. N. Berthrong, What Would Confucius Do? Wisdom and Advice on Achieving Success and Getting along with Others (New York, 2005); and Jim McBride, “Team Blessed to Have Damon," Boston Globe, 31 Oct. 2004, www.boston.com/ sports/baseball/redsox/articles/2004/10/31/team_blessed_to_have_damon/

4. See John D. Caputo, What Would Jesus Deconstruct? The Good News of Postmodernity for the Church (Grand Rapids, Mich., 2007).

5. For literature on Sheldon and his novel, see Gregory S. Jackson, "'What Would Jesus Do?': Practical Christianity, Social Gospel Realism, and the Homiletic Novel," PMLA 121, no. 3 (2006): 641-61; Timothy Miller, Following "In His Steps": A Biography of Charles M. Sheldon (Knoxville, Tenn., 1987); Paul S. Boyer, “In His Steps: A Reappraisal,” American Quarterly 23 (Spring 1971): 60-78.; and James H. Smylie, "Sheldon's In His Steps: Conscience and Discipleship," Theology Today 32 (Apr. 1974): 32-45. Recent journalistic accounts of the WWJD? phenomenon also usually trace it back to Sheldon. See Damien Cave, "What Would Jesus Do-About Copyright?" Salon.com, 25 Oct. 2000, salon.com/business/feature/200o/10/25/ wwjd, and Emily Nussbaum, "Status Is . . f for Evangelical Teen-Agers; Jewelry for Jesus," New

DANiEL SHORE is an assistant professor of English at Grinnell College, where he teaches Renaissance literature. He is completing a book titled Otherworldly Persuasions: Milton and the End of Humanist Rhetoric. This essay is part of a new book project, Cyberformalism, on literary form in the digital archive. 
While Sheldon's novel is an extremely influential document, and one that I will discuss here, it is only a waypoint in a longer history that runs back to the seventeenth century. It was then that preachers and theologians began to use a new kind of ethical formulation that challenged Christians to do not as Christ did but rather as he would do. To put too fine a point on it, the subjunctive mood first enters the English discourse of imitatio Christi in 1631. This event-what is properly understood as a syntactic event-is among the most definitive in the tradition's two-thousand-year history. It marks a dramatic change in the dynamics of Christian imitation. The cause of this modal shift, I will argue, is a deepening sense of the disparity between the modern world and the authoritative past of the Gospels. The subjunctive enters the discourse of imitatio Christi as a way to overcome this disparity. It imaginatively bridges the historical gap between the life of Jesus and the lives of his followers, allowing his example to serve as a guide even in a radically changed world. The effects of this modal shift reach well beyond the religious and ethical spheres into modern philosophy, literature, politics, and (as I have already noted) popular culture. Especially among North American Protestants, what would Jesus do? has become the dominant form of imitatio Christi in modernity.

In what follows I attempt to establish the seventeenth-century origins of subjunctive imitation and then sketch out its history to the present day. In doing so I hope to lay down a pattern, however tentative and imperfect, for a method of inquiry that I call the genealogy of syntactic forms. Such inquiry begins with the thesis that discourses undergo significant changes in syntactic usage irreducible to changes in the grammar of the language. Scholars of the humanities have long been adept at telling certain kinds of historical narratives. On the one hand, we have ample histories of largescale generic forms like the novel, the epic, the sonnet, or the sermon. These are the forms that are most visible when we consider a text as a whole and ask, what kind of thing is it? On a smaller scale, philologists have laboriously pieced together the histories of individual words. These histories come to the fore when we ask of a text, what is it made of? At the same time, of course, scholars have mapped out changes in the ideas and contexts that animate words and genres alike.

Where scholarship has largely left off, however, is in understanding the history of local forms like syntax. Unlike generic forms, these forms do not

York Times, 15 Nov. 1998, www.nytimes.com/1998/11/15/magazine/status-is-for-evangelical-teen-agers -jewelry-for-jesus.html 
immediately present themselves when we ask what kind of thing a work is. ${ }^{6}$ Unlike individual words or the ideas that animate them, syntactic forms do not come to the fore when we ask what a work is made of. For this reason they have largely escaped historical study and interpretation. The normal thing literary scholars do with syntax is decode it, turn it into meaning. Of course, many talented critics-Stanley Fish and Christopher Ricks come to mind-have found compelling ways of describing syntax. But a third task has remained largely unattempted: to give syntactic forms a history.7

There is a further, practical reason why syntactic forms have generally been neglected as the subject of historical study. Only now, with the development of a comprehensive digital archive, are syntactic genealogies becoming possible. After sketching one such genealogy-the origin and rise of the subjunctive mood in the discourse of imitatio Christi-I will return to the role of the digital archive in investigations of this kind. When combined with advanced search tools, this archive will enable us to perform plural reading, a term I coin in contradistinction both to traditional close reading and the distant reading recently championed by Franco Moretti.

\section{"Do as I Have Done"}

The practice of imitatio Christi is rooted in numerous passages from the New Testament. Some enjoin us to "follow" Christ, since "he that taketh not his cross, and followeth after me, is not worthy of me" (Matt. 10:38). Others are written in the language of likeness and exemplarity: "For I have given you an example, that ye should do as I have done to you" (John 13:15). Presenting himself as a model that leads us back to Christ's own, Paul enjoins his readers, "be followers of me, as I am of Christ" (1 Cor. 11:1). The first epistle of John 2:6 instructs, "he that saith he abideth in him ought himself so to walk, even as he walked." In Romans we are told to "put ye on

6. Generic forms can also operate at the local level. For a seminal study of genre as a local form, see Barbara K. Lewalski, "Paradise Lost" and the Rhetoric of Literary Forms (Princeton, N.J., 1985).

7. Recent years have witnessed a growth in attention to grammar and syntax as historical phenomena, especially among scholars of early modern literature. See David Schalkwyk, Speech and Performance in Shakespeare's Sonnets and Plays (New York, 2002); Lynne Magnusson, Shakespeare and Social Dialogue: Dramatic Language and Elizabethan Letters (New York, 1999); and especially Brian Cummings, The Literary Culture of the Reformation: Grammar and Grace (New York, 2002). The genealogy of syntactic forms draws on the methods and tools of historical linguistics and on the related fields of corpus linguistics and discourse analysis. But because it is concerned with limited discourses and traditions, it will not, as a rule, contribute to our understanding of the history of the grammar of the language. Tracking the history of the subjunctive mood in the tradition of imitatio Christi will not tell us anything, for example, about the processes of grammaticalization and lexicalization that are of central concern to historical linguistics. 
the Lord Jesus Christ" (13:14) and directed "to be conformed to the image" of the Son (8:29). Charles Sheldon's novel In His Steps takes its title from 1 Peter 2:21: "Christ also suffered for us, leaving us an example, that ye should follow his steps." For our present purposes we need only notice one thing about these passages: they all exhort us to imitate what Christ did do, not what he would do. It is perfectly conceivable, from the standpoint of grammatical usage, that these injunctions could have employed the subjunctive formulation. The Golden Rule- "Do unto others as you would have them do unto you"-is expressed in the subjunctive in both the Greek New Testament and the King James translation. ${ }^{8}$ And yet the question of what Christ would do is never raised.

The passages of Scripture quoted above provide the vocabulary and set the mood, as it were, for over a millennium and a half of writing about imitatio Christi. In one sermon Origen addresses his counsel to "you who follow Christ and are His imitator." Cyprian gives a near synopsis of Scriptural proof texts when he writes, "he follows Christ who follows His precepts, walks by the path of His teaching, pursues His steps and ways, [and] who imitates that which Christ both taught and did." Ambrose insists that "he who follows Christ should according to his abilities imitate Him, in order to meditate within himself His precepts and examples of divine deeds." Jerome cautions that as adults we cannot copy Christ in every detail: "since we are men, and cannot imitate the nativity of the Saviour, we at least imitate His way of life." 9 Augustine asserts in The City of God that "the highest duty of religion is to imitate him whom you worship." ${ }^{10}$ Pierre Abélard claims that God became incarnate "in order to instruct us truly in the doctrine of justice both by preaching and also by the example of His bodily way of life" ("I," p. 184). Thomas Aquinas writes that Christ allowed himself to undergo temptations at the hands of Satan "to give us an example: to teach us, namely, how to overcome the temptations of the devil,"

8. In the King James version: "Therefore all things whatsoever ye would that men should do to you, do ye even so to them" (Matt. 7:12; compare Luke 6:31). The Greek New Testament employs the subjunctive for both thetcte and poiosin. Vernacular translations are less consistent; William Tyndale employs the subjunctive, but Martin Luther's 1545 translation and the Wycliffe translation do not. The subjunctive is most clearly formulated in the colloquial version of the rule I grew up with and have given in the main text.

9. Quoted in Giles Constable, "The Ideal of the Imitation of Christ," Three Studies in Medieval Religious and Social Thought (Cambridge, 1995), pp. 151, 154, 155; hereafter abbreviated "I." These quotations are meant, of course, to be representative rather than exhaustive. Extensive searching in the Patrologia Latina and Acta sanctorum has yielded only further instances of indicative imitation. For technological reasons I discuss later these searches cannot yet be wholly conclusive.

10. Augustine, The City of God against the Pagans, trans. and ed. R. W. Dyson (Cambridge, 1998), bk. 8, chap. 17 , p. 338. 
although he argues that no less than Christ's entire life as a man on earth should be regarded as a model of Christian behavior. ${ }^{11}$

Every aspect of Christ's humanity was seen as an ideal for imitation. In a sermon by Bernard of Clairvaux, Christ, speaking in propria persona, says that he went through each stage of human life "in order that My conception may cleanse yours, My life instruct yours, My death destroy yours, My resurrection proceed yours, My ascension prepare for yours" ("I," p. 189). Special note should be given to the fifteenth-century Imitation of Christ, widely ascribed to Thomas à Kempis. Although written as a manual for monastics and ascetics, it became one of the most popular devotional works among lay Catholics and Protestants alike. Its opening passage begins with quotation ("Oure lord saip, 'he pat folowip me gop not in darkenes'"), moves on to explication ("we are amonysshed to folowe his lyf and his maners"), and then ends with exhortation ("Wherefore lete oure souereyn studie be in pe lif of Ihesu crist"). ${ }^{12}$ This progression, from indicative to imperative, from exposition to admonition, is repeated throughout the work.

The relative consistency of these utterances, written over a span of nearly sixteen hundred years, conceals enormous variations in practice. For some, imitating Christ demanded simple charity to one's neighbors; for others, like Margery Kemp, it required traveling to the Holy Land to visit the Seven Stations of the Cross; while for still others, like St. Francis of Assisi, it involved receiving the stigmata, the bodily marks of Christ's suffering. ${ }^{13}$ Nicholas Love's proem to The Mirror of the Blessed Life of Jesus Christ, an early fifteenth-century translation of the pseudo-Bonaventuran Meditationes vita Christi, illustrates the adaptive fluidity of medieval accounts of imitation. One of the chief tasks of the proem is to explain why the "meditacions" it precedes are able to narrate "cristes lyfe more pleyne in certeyne partyes pan is expressed in the gospell of pe four euaungelistes." The pseudo-Bonaventuran text adds new details and events to the authoritative accounts of Scripture and even includes descriptions of "speches or dedis of god in heuen \& angels or opere gostly substances." Love excuses this "drawynge oute" of the "boke of cristes lyfe" on the grounds that it is "moste spedefull \& edifyng to hem pat bene [of] symple vndirstondyng."

11. Thomas Aquinas, Summa Theologiae, trans. Samuel Parsons and Albert Pinheiro, 61 vols. (New York, 1964), 53:71.

12. Thomas à Kempis, The Earliest English Translation of the First Three Books of the "De Imitatione Christi," ed. John K. Ingram (London, 1893), 1.i.1-8, p. 2.

13. On the diversity of medieval imitative practices, see "I"; Caroline Walker Bynum, Holy Feast and Holy Fast: The Religious Significance of Food to Medieval Women (Berkeley, 1987); and David Aers and Lynn Staley, The Powers of the Holy: Religion, Politics, and Gender in Late Medieval English Culture (University Park, Penn., 1996). 
The stirring of devotion in "symple soules" justifies, for Love, the attempt to "ymagine and penk diuerse wordes \& dedes ... and oper" events that are "not writen" in the Gospels. Even as he acknowledges that his book represents "diuerse ymaginacions," Love defends its truthfulness by quoting the Gospel of John's admission that "alle po pinges that Jesus dide, bene not written in Pe Gospelle" (see John 21:25). In other words, The Mirror of the Blessed Life of Jesus Christ imagines a great deal, but what it imagines might nevertheless have been real. For Love, the only limitation on such imagining is that it should not be "azeyns pe byleue or gude maneres" of its readers. ${ }^{14}$ This principle offers wide interpretive and imaginative latitude. One may imagine deeds and actions not recorded in the Bible when it is appropriate and "edifyng"- useful for moral instruction. And yet even in their reliance on "ymaginacion," the meditations firmly bind themselves, syntactically and conceptually, to describing what Christ did do. The question of what Jesus would do in "oper" circumstances is never raised.

In addition to seeing many medieval imitative practices as idolatrous rituals, the Reformation challenged the larger importance and centrality of imitatio Christi. Because Martin Luther held faith rather than works to be the cause of salvation he promoted Christ's role as "sacrament" above his role as "exemplar." And yet he too enjoins imitation in much the same manner as his predecessors: "In Christ we see the height of patience, gentleness, and love, and an admirable moderation in all things. We ought to put on this adornment of Christ, that is, imitate these virtues of His." ${ }^{15}$ Like those who precede him, Luther speaks of imitatio Christi as a form of mimetic reproduction, instructing believers to reproduce Christ's example within their own lives.

\section{"Were He in Our Case and Condition"}

Seventeenth-century preachers and theologians are the first to begin to speak of imitating Christ in a new mood. In 1631 Edward Reynolds, a prominent Presbyterian preacher who would later become Bishop of Norwich, enjoins his readers: "What ever action therefore you goe about, doe it by Rule, enquire out of the scriptures whether Christ would have done it or no, at least whether he allow it or no. ${ }^{{ }^{16}}$ Reynolds expands the imitation

14. Nicholas Love, The Mirror of the Blessed Life of Jesus Christ, ed. Michael G. Sargent (Exeter, 2004), pp. 10, 11.

15. Martin Luther, Lectures on Galatians and Lectures on Genesis, in Luther's Works on CDROM, trans. pub., ed. Jaroslav Pelikan and Helmut T. Lehmann, 55 vols. (St. Louis, 1963), 26: 352, 4:192.

16. Edward Reynolds, "The Life of Christ," Three Treatises of "The Vanity of the Creature," 
Daniel Shore / WWJD?

of Christ to include not only those actions he in fact performed but also those he enjoined by means of a general rule, or allowed, or would have done himself. The subjunctive does not, of course, immediately displace more traditional, indicative ways of speaking about imitation; the two often appear together, as complements. The great divine, Jeremy Taylor, writes in his 1656 Holy Living and Dying that "when you are to do an action, consider how Christ did, or would do, the like, and do you imitate his example, and transcribe his copy." ${ }^{17}$ Here the subjunctive is introduced only as a qualification, working alongside the indicative to cover all instances of moral action.

The seventeenth-century preachers and divines who employ the subjunctive often express concerns about the disparity between Christ's life and their own. In 1649 Taylor concedes that Jesus' life is not able to provide an appropriate model for all of his seventeenth-century peers and parishioners. "Some states of life also there are," he writes, "which Jesus never lead." In the lives of his readers, however, "many cases do occurre, which need a president, and the vivacity of an excellent example." Examples are necessary because rules do not make "provision for all contingencies," and they are, in any case, easily perverted by the "subtlity" of men. Taylor counsels those who lead lives that Christ never led, and who confront "cases" and "contingencies" he never encountered, to consider "what he would have done in the like case ... in such cases we must alwayes judge on the strictest side of piety and charity ... for so would the righteous and mercifull Jesus have done."18

There is much virtue in would; it allows even those who lead radically different lives from Christ, and who live in radically different worlds, to look to him as a pattern of moral behavior. In 1672 the preacher Thomas White laid out the logic for considering Christ's example in the subjunctive mood, pledging that he "shall endeavour in every action that I do, and word that I speak, to remember if I can, whether there be any parallel instance in the life of Christ, if there be, I shall make that my pattern, and do likewise, but if there be none, that I can think of, then I would do that which in my conscience I think Christ would have done in like case. ${ }^{19}$ By

\footnotetext{
"The Sinfulnesse of Sinne," and "The Life of Christ": Being the Substance of Severall Sermons Preached at Lincolns Innes (London, 1631), p. 427.

17. Jeremy Taylor, Holy Living and Dying (1656; New York, 1865), p. 247.

18. Taylor, The Great Exemplar of Sanctity and Holy Life According to the Christian Institution (London, 1649), p. 9.

19. Thomas White, A Method and Instructions for the Art of Divine Meditation (London, 1672), p. 304 .
} 
White's logic, believers should practice indicative imitation ("do likewise") when they are able to discern congruity or parallelism between Christ's life and their own. They should practice subjunctive imitation ("would have done") only when faced with incongruity or difference. The subjunctive thus functions as a practical response-a linguistic adaptation-to a perceived difference.

Every use of the subjunctive implies a condition. The question who would Jesus bomb? is implicitly accompanied by something like this counterfactual hypothesis: if Jesus were to possess bombs. But the condition can be expressed in plenty of other ways: if Jesus were alive now, if he had been confronted with similar threats, as commander in chief, in our situation, and so on. Whether implicit or explicit, the purpose of the condition is to control for the relevant differences between Jesus' situation and our own by designating a possible world in which the question can be meaningfully asked.

While twenty-first-century Christians tend to leave the condition unstated, seventeenth-century writers often state or, in the case of the preacher John Everard, overstate the condition. Follow Christ "as our pattern," Everard exhorts his readers in 1657, "that in what condition soever we are in, whatever in such a condition Christ himself would do, were he in our case and condition, the same do we." Later he directs his readers to do "the same things as our Saviour would do in thy case, were he upon earth." Later still he rolls out the condition no less than three times, recommending "that what ever Christ would do were he on earth, in my case, in my calling and condition the same do we." ${ }^{20}$ Everard's contemporaries usually acknowledge the difference of Christ and his world in less emphatic terms. The nonconformist minister Richard Steele, for example, instructs his readers to treat others "as you think David, Paul, or Christ would do if they were here." ${ }^{21}$

In the indicative form characteristic of medieval imitation, Christ's example posits a definite set of events, experiences, and actions that must be ritualistically reproduced in the life of all believers. As I stressed earlier, this repetition leads to an enormous diversity of practices and should not be understood as thoughtless or mechanical repetition. Even so, the believer begins with Christ's pattern and then shapes his or her own life accordingly. The subjunctive reverses this priority. The believer begins with his or her own present situation (what should I do about $\mathrm{x}$ ?) and then turns to

20. John Everard, The Gospel Treasury Opened (London, 1657), pp. 132, 179, 206; my italics.

21. Richard Steele, A Plain Discourse upon Uprightness Shewing the Properties and Priviledges of an Upright Man (London, 1672), p. 137. 
Christ's life as a way of imagining the right answer. No longer are actions obligatory merely because Jesus performed them. The subjunctive allows one to perform a Christ-like action that Christ never performed himself even as it frees one from the obligation to perform all, or even any, of Christ's actions in order to be Christ-like. What Taylor called The Great Exemplar ceases to be a compulsory pattern and instead serves only as an aid to ethical deliberation.

With the shift to the subjunctive, imitation retreats from public viewfrom outward, ritualized actions and visible, bodily marks. ${ }^{22}$ Asking what Jesus would do amounts to a kind of intersubjective thought experiment that requires the believer to imagine Christ's response to his or her own situation. While Bishop of Norwich in 1652, Joseph Hall offered his readers this meditation:

What ever I am about to do, or speak, or affect; let me think: If my Saviour were now upon earth, would he do this that I am now putting my hand unto? would he speak these words that I am now uttering? would he be thus disposed as I now feel my self? Let me not yeeld my self to any thought, word or action which my Saviour would be ashamed to own. ${ }^{23}$

These questions are not concerned with direct mimesis; there are no definite actions enjoined or prohibited. Instead they are concerned with the process of deliberation itself, filtered through the imagined perspective of Christ. From this perspective the deliberator considers not only what Christ would do, but also what he would feel, his affective disposition, and whether he would be ashamed in a similar situation. This meditation, which creates a sense of intersubjective contact across vast differences of history and culture, is licensed by the counterfactual hypothesis, "if my Saviour were now upon earth.”

\section{“A Different Age"}

Although the subjunctive mood continues to appear throughout the eighteenth century, only around the middle of the nineteenth does it become a widespread form of imitatio Christi. ${ }^{24}$ Naturally, discussions of

22. I do not mean to deny the innerness of earlier imitative practices but rather to emphasize the turn away from outward, public displays of imitatio Christi.

23. Joseph Hall, Holy Raptures; or, Pathetical Meditations of the Love of Christ (London, 1652), pp. 52-53.

24. For eighteenth-century instances of subjunctive imitation, see John Smith, The Moral Telescope; or an Essay on the Nature of Moral Action (Berwick, 1789), p. 105; Jacques Saurin, Sermons on the Attributes of God, trans. pub., 4 vols. (Cambridge, 1775-82), 2:133-34; Thomas 
Christ's example occur most frequently in the works of preachers and religious writers: in collected sermons, periodicals, and the rapidly expanding varieties of popular devotional materials that followed upon the reawakening religious sensibilities of the period. In 1832, for example, the minister Isaac Ambrose writes,

would my blessed Saviour if he were upon earth, do thus and thus? ... Would he have spent such a life upon earth as I do? ... Is this the life that Christ led? Or, if he were to live again, would he live after this manner? O but would Christ speak thus? Would this be his language? Would such a rotten or unprofitable speech as this drop from his honey lips?25

Once again, as in Taylor's Holy Living, we witness the indicative ("the life that Christ led") and subjunctive ("Or, if he were to live") standing side by side, with the latter addressing those instances of discontinuity not covered by the former. But now the subjunctive is primary and the indicative only a momentary interpolation.

In a fragment from his collected works, published in 1836, the Reverend Richard Cecil cautions that heterogeneity and difference must be attended to even when employing the subjunctive:

We must take care when we draw parallel cases, not to take such as are not or cannot be made parallel. For instance-we may ask, before we act, "What would Jesus Christ do in this case? or what would St. Paul?" but we cannot be guided by this rule in every thing, because Christ's mission was peculiar: it was an unparalleled event.

Cecil is not insisting on the inimitability of Christ's divine or supernatural role; he merely warns that "in the conduct peculiar to our station, our application of these examples must be governed by circumstances. ${ }^{206}$ By the late nineteenth century subjunctive imitation had become especially popular among American evangelicals; the prominent evangelist D. L. Moody instructs his audience, "whenever we are tempted, if we would just

Robinson, Scripture Characters: or, a Practical Improvement of the Principal Histories in the Old and New Testament, 4 vols. (London, 1800), 3:79; and Edmund Calamy, The Nonconformist's Memorial: Being an Account of the Ministers, Who Were Ejected or Silenced after the Restoration, 2 vols. (London, 1778), 2:614.

25. Isaac Ambrose, Looking unto Jesus: A View of the Everlasting Gospel, or, the Soul's Eyeing of Jesus, as Carrying on the Great Work of Man's Salvation, from First to Last (Pittsburgh, 1832), p. 327.

26. Richard Cecil, Remains of the Reverend Richard Cecil, ed. Josiah Pratt (Philadelphia, 1843), p. 267. 
ask the question, 'I wonder if Jesus would do it if He were here?' and be willing to take Him as our guide, what a help it would be!" ${ }^{27}$ But these are by no means questions asked only by evangelicals; a piece in the 1848 volume of the Church of England Magazine, a periodical produced by the "Clergymen of the United Church of England and Ireland," advises, "Often put yourself in these inquiries: what am I doing? Where am I? What would Jesus Christ have been doing in my circumstances?"28

In the latter half of the nineteenth century subjunctive imitation begins to spread from formal sermons and doctrinal writings into popular religious poems, hymns, short stories, and novels. Friendly Words for Our Girls, published in 1875 for the "Members of the Girl's Friendly Society," an organization founded by the Church of England to help urban women working in textile mills, gives us a hymn that opens with these lines:

If to sinful deeds and actions

Men are tempting you,

Stop and ask yourself the question,

"What would Jesus do?" 29

The Home Missionary, the periodical of an interdenominational organization that aimed to assist in the development of Christian congregations, published a poem in 1889 entitled "What Would Jesus Do?" The closing lines hark back to 1 Peter 2:21:

Now if it be our purpose

To walk where Christ has led,

To follow in his footsteps

With ever careful tread;

O let this be our watchword,

Twill help both me and you,

To ask in each temptation,

"What would Jesus Do?"

The poem is followed by this entreaty: "Dear Young Friends-Will you take this as your watchword for 1889 - 'WHAT WOULD JESUS DO?' "30

While these poems place special emphasis on traditional virtues like

27. D. L. Moody, Glad Tidings: Comprising Sermons and Prayer-Talks (New York, 1876), p. 315 .

28. "The Christian Master's Present to His Household," Church of England Magazine, 22 July 1848 , p. 62.

29. A. Marryat, Friendly Words for Our Girls: A Series of Readings for Daily Use (London, 1875), p. 76.

30. "What Would Jesus Do?" The Home Missionary 61 (Jan. 1889): 430. 
temperance and chastity, subjunctive imitation also offers room for other, more disruptive questioning. The True History of Joshua Davidson, an 1872 novel by Elizabeth Linton, is exemplary in this regard. Linton's tale of "practical Christianity" tells the story of Joshua, a nineteenth-century carpenter who decides to live out his life according to the example of Christ. But he soon comes to find that example limited by the historical conditions in which Christ lived. Jesus was "the product of His time," Joshua argues, and while he "did His best to remedy" suffering and injustice "by proclaiming the spiritual equality of all men," he nevertheless "left the social question where He found it." Christ's failure to advocate "radical revolution" leads Joshua to a shocking assertion: "The modern Christ would be a politician." Instead of "mak[ing] the poor contented" with their miserable conditions, the modern Christ "would raise the whole platform of society" and "would work at the destruction of caste, which is the vice at the root of all our creeds and institutions." ${ }^{31} \mathrm{He}$ would, in short, be a communist. Like many present-day spin-off questions, these assertions display a spirit of overt opposition. Joshua uses the subjunctive mood to expose the historical limits of Christ's example and, more pointedly, the failure of the Church to go beyond those limits. What Jesus would do functions not as a complement to, but as a criticism of, what he did do. (Linton's novel ends, it is worth noting, with the leaders of the Church of England kicking Joshua to death.)

In the later years of the century the example of Christ was more commonly employed to advocate Christian reform than communist revolution. Gregory S. Jackson has observed that "homiletic novels," which "aimed to facilitate private devotion, strengthen moral autonomy, and foster social engagement," were "largely discussed in the subjunctive mood." ${ }^{32}$ The homiletic novel of greatest historical significance is Sheldon's In His Steps, the subtitle and slogan of which is What Would Jesus Do? As we noted, this question has a long history and was already current in the culture when Sheldon, a preacher from Topeka, Kansas, and an adherent to the Social Gospel movement, began in 1891 to write the narrative sermons that eventually constituted his most popular novel. But there is little doubt that In His Steps is responsible both for fixing the question in its now-familiar form and for establishing its immense popularity even up to the present day. First published serially in 1896, and then as a novel in 1897 , it is by many estimates the best-selling novel of the nineteenth century. ${ }^{33}$

31. Elizabeth Lynne Linton, The True History of Joshua Davidson (London, 1872), pp. 80-81.

32. Jackson, "What Would Jesus Do?"” p. 642.

33. See Charles Sheldon, In His Steps (What Would Jesus Do?) (1897; Uhrichsville, Ohio, 1985); hereafter abbreviated IHS; this is one of countless editions published in the twentieth 
Sheldon tells the story of a small-town congregation that pledges "for an entire year, not to do anything without first asking the question, 'What would Jesus do?'” (IHS, p. 15). Those who take the pledge dramatically upend their lives in order to help the poor, strengthen the faith, and fight the evils of liquor. Sheldon's novel is a testament to how dominant subjunctive imitation had become by the end of the nineteenth century. To its characters the traditional, indicative injunctions of Scripture seem unfamiliar and lifeless, like relics from a distant past in need of explanation. After listening to a competent but uninspired sermon on 1 Peter 2.21"Christ also suffered for you, leaving you an example, that ye should follow his steps"” (IHS, p. 1) - one character asks, "'What would Jesus do? Is that what you mean by following His steps?" (IHS, p. 9). Only when accompanied by or translated into the subjunctive do Scriptural injunctions begin to have transformative power, providing characters with an intuitive way of conquering their selfish instincts for the sake of true Christian morality.

Sheldon's characters are explicitly and acutely aware of the disparity between Christ's world and their own. They acknowledge that they can only ever imitate "Jesus' probable action" and must therefore rely on their own uncertain judgments (IHS, p. 132). When first taking the pledge to follow Christ, one young woman asks, "Who is to decide for me just what He would do in my case? It is a different age. There are many perplexing questions in our civilization that are not mentioned in the teachings of Jesus. How am I going to tell what He would do?" (IHS, pp. 17-18). Sheldon himself develops the problem of historical difference in the preface to Jesus Is Here! the sequel to In His Steps, writing that "the world to-day is far different from the world into which the historical Jesus was born. It is so different, that entirely new problems relating to human conduct face the modern Christian." Despite these differences, he argues, we must "ask what would be the attitude of Jesus as he faced the complex conditions of modern society." ${ }^{4}$ For Sheldon and his characters, "what would Jesus do?" is a practical way to connect "the world to-day" ever more closely to the "different age" of the Gospels.

Throughout In His Steps, characters ask themselves variations on the

century. See Erin Smith, "'What Would Jesus Do?': The Social Gospel and the Literary Marketplace," Book History 10 (2007): 193-221, and Miller, Following "In His Steps," pp. 66-102 for a discussion of sales. Because of the peculiar publication history of In His Steps (lack of copyright protection meant it was widely pirated) exact sales estimates are impossible.

34. Sheldon, "Jesus Is Here!" Continuing the Narrative of "In His Steps (What Would Jesus Do?)" (New York, 1914), p. ii. 
novel's slogan, such as, ““"What would Jesus do as Edward Norman, editor of a daily newspaper in Raymond?"'” (IHS, p. 131). This sort of question cannot be meaningfully asked in the indicative. Jesus Christ did not do anything as Edward Norman, editor of the daily newspaper in Raymond. By the same token, we can ask, what would Jesus drive? but Jesus did not, of course, drive anything (apart, that is, from a donkey and, if we trust Milton, a flying chariot). The subjunctive opens up the imitation of Christ to the potentially infinite set of moral issues that confront us now, in our own world, and in worlds more different still. In the writings of Sheldon and his successors, these possibilities are reflected in the proliferation of questions based upon the subjunctive. Published twenty-five years after the original novel, Sheldon's In His Steps To-day addresses the pressing issues of the early twentieth century through a series of ten chapters titled with questions. Each question begins, "What would Jesus Do..." and then continues, "in the coalfields," "in politics," "with the press," "in the railroad world," "with international affairs," and so on. ${ }^{35}$ This proliferation of questions has, as we began this essay by observing, continued on a larger scale in our own day.

Since the popularization and proliferation of the subjunctive in the late nineteenth century, the ways in which we speak about imitating Christ have undergone relatively few changes. To the question, what would Jesus do? the twentieth century has contributed mainly its predilection for abbreviations and self-help, as well as its talent for parody, mass-marketing, and merchandising.

\section{Historical Solitude}

It is in Sheldon's acknowledgement that "the world to-day is far different from the world into which the historical Jesus was born" that we find the most plausible explanation for the modal shift that took place in the discourse of imitatio Christi during the seventeenth century. Such acknowledgements exhibit what Thomas Greene has famously described as "historical solitude." According to Greene's thesis, no one before Dante was "fully sensitive to the fact of radical cultural change." Only in the Renaissance did writers and thinkers develop a sense of "estrangement," "remoteness," and "cultural distance" from a past that was, they realized, "never fully recoverable." And yet early moderns saw cultural discontinuity not simply as a fact to be accepted but rather as a predicament to be dealt with, struggled against. It is because of this struggle that Renaissance

35. Sheldon, preface to In His Steps To-Day: What Would Jesus Do in Solving the Problems of Present Political, Economic, and Social Life? (New York, 1921), p. 11. 
art and thought display what Greene calls "the rage for contact with the past." ${ }^{36}$

The modal shift that took place in the early seventeenth century is one relatively quiet indicator of this rage, a linguistic means of making contact with an increasingly remote past. But a weak version of historical solitude, one less monumental and more flexible than Greene supposed, provides a better explanation for this shift. We need not contend that the awareness of radical cultural change arises like a tropical dawn in the minds of Dante and Petrarch. A weak version of the thesis would allow for an awareness that deepened over time, sometimes gradually, sometimes in fits and starts. Greene associates historical solitude with the study of classical texts by fourteenth- and fifteenth-century humanists, but a weak version must allow for asynchronous development across discourses if it is to explain why a sense of rupture begins to appear in discussions of imitatio Christi only some two centuries later. The larger implication of this asynchronous development is that historical solitude occurs not in the minds of individual writers but in particular discourses. A sixteenth-century humanist may be fully conscious of the remoteness of ancient Greece or Rome, for example, and yet still maintain an intuitive sense of closeness and contemporaneity with first-century Christians. We later will see that Erasmus exhibits precisely this disjunction.

A weak version of Greene's thesis must account for the fact that changes in language usage bear a complex causal relation to historical consciousness. The subjunctive may precede or follow, as either a harbinger or lagging indicator, an explicit or conscious sense of remoteness. It may function as an adaptive response to a burgeoning awareness of cultural distance that is not fully manifest or, conversely, precipitate further such awareness. The seventeenth-century writers quoted above employ the subjunctive to control for differences in what Taylor calls "cases" and "contingencies." Despite acknowledging these differences, however, they do not, as Sheldon and Linton do nearly two hundred and fifty years later, explicitly identify them as the result of historical or cultural change.

Finally, a weak version cautions us against seeing the growth of historical consciousness as an unequivocal story of progress. While the shift to subjunctive imitation signals a deepening sense of difference, it does not, therefore, represent an unqualified advance from historical blindness to historical insight. Rather, the syntactic form of what would Jesus do? introduces its own kind of blindness. In seeking to join together the immediate

36. Thomas M. Greene, The Light in Troy: Imitation and Discovery in Renaissance Poetry (New Haven, Conn., 1982), pp. 17, 9. 
present and the distant past, the condition ("If my Saviour were now upon earth") effectively elides everything that stands between. Seventeenthcentury Protestants often referred to the period that stood between them and Christ as the Middle Ages and frequently construed it as an era of pathless error and corruption. In the present day what stands between us and Christ lacks a name, but subjunctive imitation consistently elides it nonetheless. Although asking what Jesus would do is a response to the discontinuity of past and present, the question is unable to take account of history as the process of incremental change, accretion, and tradition that provides the only connection between past and present. When present-day Christians ask themselves what Jesus would eat, for example, they consider both Christ's diet and their own, but they invariably — and quite practically-ignore the vast and complex history of dietary practices that link the two together. Blindness to historical process is the price modern imitation pays for its ability to overcome historical difference.

\section{Glorified Indices}

I have attempted thus far to narrate the history, not of a word, an idea, or a genre, but of a syntactic form within a specific discourse. I have argued that the shift from indicative to subjunctive imitation is a response to changes in historical consciousness. Let it be said that I could not have told this story without a number of digital archives: mainly, Early English Books Online, Google Book Search, Eighteenth-Century Collections Online, and the Patrologia Latina Database. ${ }^{37}$ The questions I have asked, and the answers I have suggested, would not have been possible in the absence of these new (and still incomplete) technological resources. Take, for example, the claim I made earlier, that the subjunctive mood appears in the tradition of imitatio Christi for the first time in 1631. Standards of good scholarship would require one to buttress this claim with qualification and support. One would admit that the claim can be made with greater confidence in English and in Latin than in other modern languages; that an earlier instance is, of course, always possible; that the absence of the subjunctive in even a wide sample of pre-160o texts does not entail its absence in all. In support of the claim one would begin by pointing to further

37. To the extent that I have relied on multiple archives, along, of course, with more traditional media, the singular term digital archive is a convenient fiction. As Anthony Grafton writes, "the supposed universal library, then, will be not a seamless mass of books, easily linked and studied together, but a patchwork of interfaces and databases, some open to anyone with a computer and WiFi, others closed to those without access or money" (Anthony Grafton, "Future Reading," The New Yorker, 5 Nov. 2007, www.newyorker.com/reporting/2007/11/05/ 071105fa_fact_grafton). 
evidence, such as Christopher Sutton's Disce Vivere: Learne to Live, a 1602 devotional manual that manages to show, in over six hundred pages, "that the life of Christ is the most perfect patterne of direction to the life of a Christian" without asking, at any point, what Christ "would do." ${ }^{8}$ One would note that, although an earlier instance of the subjunctive might modify the time line, it would not necessarily overturn the larger narrative I have offered here.

I rehearse these arguments, however, to suggest that they will become less required as digital archives become more comprehensive. At some point we will likely speak about the advent of subjunctive imitation and similar syntactic events in much the same way we now speak about other facts of literary, linguistic, or intellectual history. Like other kinds of facts, facts of syntactic history will remain open to contestation and revision; in this respect they resemble the first recorded usages of the philologist. But the kinds of evidence given to support these facts will change. A well-made search string - one that is both thorough and precise-will itself constitute good evidence for a claim of the kind I make above. ${ }^{39}$ To refute this evidence will require either a better search string or a more comprehensive archive.

In the past twenty years there have been enormous increases in the size of digital archives. But there have been only a few changes in the way we search archives of any size. Search tools have thus far remained fixed at or near the level of the nondigital tools-card catalogs, concordances, and indices - they replace. To these older technologies search engines have no doubt added some useful features; it is now possible to search for a phrase rather than an individual word, to use Boolean operators to add and exclude possibilities, and, in rarer cases, to perform a proximity search, which locates words that appear within a specified distance of one other. Nevertheless, search tools have not aimed to do much more than the traditional tasks of finding works, words, and phrases. Google Book Search refers to itself as either an "index" or a "card catalog." 40 Eric Schmidt, Google's CEO, asks us to "imagine" it as "one giant electronic card cata-

38. See Christopher Sutton, Disce Viuere: Learne to Liue: A Briefe Forme of Learning to Liue, Wherein Is Shewed, That the Life of Christ Is the Most Perfect Patterne of Direction to the Life of a Christian (London, 1602).

39. Digital archives will likely change the way we cite textual and bibliographic claims. Take the claim I made earlier, that subjunctive imitatio Christi becomes widespread around the middle of the nineteenth century. Rather than citing the bibliographic information for potentially hundreds of works to justify this claim, one might instead direct readers to a specific digital archive (for instance, Google Book Search) and a search string (for instance, "would jesus do date: $1825-1875$ ").

40. "The Point of Google," googleblog.blogspot.com/2005/10/point-of-google-print.html 
log." 41 There would be nothing wrong with such analogies (they are, after all, only analogies) if they did not prevent us from seeing search engines as tools for discovering things about our history and culture that could not be discovered otherwise. For the great majority of scholars, a search engine offers little more than a glorified index. But this limitation lies in thought, not technology.

Imagine an index that contains not simply a list of proper names, subject headings, and key concepts but also a list of verb tenses, noun phrases, modal auxiliaries, postpositioned adjectives, absolute and relative clauses, progressive and perfect verbs, and so on. Now imagine that each term in a list could limit every other, so that one could generate a further list, for example, of all instances of a key concept expressed in the progressive aspect or, say, all instances of the future perfect tense regarding a particular subject heading. Now imagine that this "index" (a term no longer suited to what we are imagining) points back not simply to a single work but, ideally, to something approaching the entire archive of extant written documents. What kinds of patterns, events, and stories would become apparent were such a tool put in the hands of scholars?

The search engine we have just imagined does not exist, but in some cases there are workarounds that allow current engines to perform similar functions. I have been able to trace modal shifts in imitatio Christi for the simple reason that in English the subjunctive mood has a distinct and independent verbal marker: the modal auxiliary would. But when syntactic features have varying morphological markers (as with highly inflected languages like Latin or Greek, in which moods are usually distinguished by vowel changes internal to the verb) these workarounds are of little help. Developing further histories of syntactic forms, especially in traditions that cross linguistic and cultural boundaries, will require two things. First, it will require more complete, correct, and accessible digital archives. As Anthony Grafton writes, "even the best search procedures depend on the databases they explore." ${ }^{42}$ Ten years ago the efforts of scholars were able to significantly improve digital archives, but their future depends mostly on the vagaries of corporations and copyright laws. Second, developing histories of syntactic forms will require more advanced search engines. Here scholars can play an active role. (In many disciplines, let us remember, scholars compete for new research technologies.)

A "syntax search" of the type we imagined above is closer than one might suppose. We already possess the most necessary component: mor-

41. Eric Schmidt, "Books of Revelation," Wall Street Journal, 18 Oct. 2005, p. 1.

42. Grafton, "Future Reading." 
phological analyzers capable of identifying the dictionary form (or lemma) of a word and parsing its grammatical features: part of speech; case, gender, number, declension; conjugation, tense, mood, voice, aspect; and so on. Morpheus, the morphological analyzer integrated into the Perseus website, is a good example; it allows users to click on any word in its Latin or Greek archive to see its dictionary form, definition, and a list of its possible grammatical functions. The limitation of such tools is twofold. First, they lemmatize words (reduce them to their dictionary forms) only in order to make word searches effective for all word forms. They cannot search for grammatical forms independently of particular words. Second, and more importantly, these tools are thus far intensive rather than extensive. They allow one to perform a full analysis of a chosen text or corpus of texts, but they do not allow one to search a large archive of unknown texts. So, for example, Morpheus might be able to identify the Latin phrase "mirabile dictu" as a supine and point us to other texts in which this phrase occurs, but it would not be capable of finding all other supine phrases in an extensive archive of Latin texts. We do not have search engines capable of searching for syntactic forms, but morphological analyzers point the way to their development.

\section{Availability}

Using advanced search tools to develop syntactic genealogies would deepen our understanding of the choices writers make. Our intuitions tell us that Shakespeare could not have written a detective novel. Milton could not have written a haiku. These intuitions are not concerned with the abstract and empty issue of logical possibility. There is nothing logically impossible about a detective novel by Shakespeare or a haiku by Milton. Our intuitions concern, rather, what we might call availability. Shakespeare could not have written a detective novel because that genre was simply not available at the time. (I leave aside the vexed question of whether he could have invented the detective novel). With regards to genre, our intuitions of this sort are clear, well developed, and testable against the history of literature as we presently have it. Similarly, we have long had reliable accounts of the availability of individual words - of first uses and changes in definition and usage. Milton could not have described Paradise Lost as a theodicy, even though it is one, because Leibniz invented the word theodicy some thirty-five years after Milton's death.

Our intuitions about the availability of syntactic forms are comparatively undeveloped. This is because we generally assume the availability of any syntactic form to be the same as the availability of that form within the grammar of the language itself. We tend to elide the matter of discursive 
availability. Certain syntactic forms that are available in the language as a whole are nevertheless unavailable within a particular discourse at a particular time and place. When, for example, I assert that Shakespeare could not have employed the subjunctive with regards to the imitation of Christ, I am not making an assertion about the constraints of his language. ("What would he do," asks Hamlet, observing the Player perform the part of Priam, "Had he the motive and the cue for passion / That I have?"). ${ }^{43}$ I am making an assertion, rather, about the constraints of a discourse.

No figure better exemplifies the complexities of discursive availability than the humanist and theologian Erasmus of Rotterdam. Because of his engagement with both classical and Christian cultures, Erasmus wrote extensively about imitating two different models: Christ and Cicero. In his Enchiridion Militis Christiani (Handbook for the Christian Soldier), first translated into English in 1534, Erasmus promotes Christ as the only perfect model for imitation. He writes that Christians must "neuer swarue nor go from the trewe patron [pattern] and example of Christe." Whoever "wryeth one ynche or nayle brede" from this example "gothe besydes the ryght pathe and ronneth out of ye way." Displaying a far greater degree of rigidity than Nicholas Love, he insists that we must "counterfayte" the life of Christ "without excepcion." "4 Like his predecessors, and like all writers until the early seventeenth century, Erasmus enjoins the imitation of Christ solely in the indicative mood.

In part because he held Christ to be the only model worth following, Erasmus was skeptical of those who sought out other models. Many humanists saw Cicero as the ideal orator and therefore aimed to copy his style as closely as possible in their own writing. Erasmus regarded such dogged imitation as unnecessary and ridiculous, but also as a kind of idolatry. His Ciceronianus, a dialogue between Nosoponus, a caricature of Ciceronianism, and Bulephorus, Erasmus's avatar, lampoons those who believe they can obtain eloquence by slavishly copying a single past model. Nosoponus at one point outrageously admits that he would rather be accounted a true imitator of Cicero than a faithful Christian. Bulephorus counters that, rather than simply imitating his writings, we should consider what Cicero would say were he alive in changed (that is, Christian) circumstances. He concludes that "if Cicero were alive now [si viveret] ... he

43. William Shakespeare, The Tragedy of Hamlet, Prince of Denmark, in The Riverside Shakespeare, ed. G. Blakemore Evans et al. (Boston, 1997), 2.2.560-62.

44. Desiderius Erasmus, Desiderius Enchiridion Militis Christiani: An English Version, trans. and ed. Anne M. O’Donnell (Oxford, 1981), pp. 11, 136, 139. 
would speak today as a Christian among Christians [dicturus esset hodie Christianus apud Christianos]." 45

It is striking that Erasmus wrote of what Cicero "would do" even though he did not write in this way about Christ. Subjunctive imitation does appear, albeit infrequently, at other points in the classical tradition. In his own Enchiridion, for example, Epictetus advises that when meeting famous people we should ask ourselves, "What would Socrates or Zeno have done [epoiesen] under these circumstances [en toutōi]?" 46 More surprising, however, is that Erasmus uses the subjunctive to precisely the opposite end to which it will later be used in the imitatio Christi tradition. He uses it to exacerbate rather than overcome historical discontinuity, to highlight anachronism. By pointing out that Cicero would behave very differently in the present, he accentuates the disparity between pagan and Christian ages and shows the absurdity of transferring a fixed model from one to another. "Thus it can happen," he writes, calling attention to this absurdity with a paradox, "that he is most a Ciceronian who is most unlike Cicero [Ciceronianus sit maxime, qui Ciceroni sit dissimillimus]." 47

\section{Plural Reading}

Beyond allowing us to look at particular works anew, the genealogy of syntactic forms leads to progressively broader and more systematic questions. Why does one seventeenth-century divine like Jeremy Taylor adopt the subjunctive while another like Richard Baxter does not? Why does the question of what Jesus would do become prominent in one cultus, denomination, language, or nation and not others? (I have not, for example, found the subjunctive in pre-nineteenth-century Catholic texts.) My current argument has been concerned only with the syntactic history of imitatio Christi. But the question of modality could be expanded to other imitative traditions as well. Every culture has its

45. Erasmus, Ciceronianus, or, A Dialogue on the Best Style of Speaking, trans. Izora Scott (New York, 1908), pp. 70-71.

46. Epictetus, Enchiridion, in The Discourses as Reported by Arrian, trans. W. A. Oldfather, 2 vols. (Cambridge, Mass., 1952), 2:78. Asking what a classical author would do was usual enough among humanists of the sixteenth and seventeenth centuries. The pedagogue Roger Ascham, for example, instructs schoolmasters to correct their students by pointing out that "Tullie would have used such a worde, not this: Tullie would have placed this word here, not there: would have used this case, this number, this person, this degree, this gender," and so on (Roger Ascham, The Scholemaster, in English Works of Roger Ascham, ed. William Aldis Wright [Cambridge, 1970], p. 184). In the introduction to his 1697 translation of the Aeneid, John Dryden writes, "I have endeavored to make Virgil speak such English as he would himself have spoken, if he had been born in England, and in this present age" (quoted in Robert Fitzgerald, introduction to Virgil, The Aeneid, trans. John Dryden, ed. Fitzgerald [New York, 1964], p. 17).

47. Erasmus, Ciceronianus, p. 78 . 
exemplars. Every culture looks to the past for models of normative behavior. Which cultures and traditions employ the subjunctive and at what point in their history? Is there a general connection between subjunctive imitation and historical consciousness, or might other causes be at work? Does the indicative always precede the subjunctive in imitative traditions, or might the reverse be true? This line of questioning could in principle be extended beyond all national and linguistic borders.

Franco Moretti has argued that in order to understand literature as a world system we must abandon traditional close reading as "a theological exercise" concerned only with the "very solemn treatment of very few texts taken very seriously." He proposes instead that we practice "distant reading," which would allow us "to focus on units that are much smaller or much larger than the text: devices, themes, tropes-or genres and systems." Systematic study of world literature must proceed "without a single direct textual reading," jettisoning the rich experience of individual poems and novels to rely instead on "poor" and "abstract" concepts. This sacrifice of the text to the gods of systematic understanding amounts to what Moretti calls "a little pact with the devil." 48

While Moretti's goal of a "comparative morphology," which he defines as "the systematic study of how forms vary in space and time," is admirable, his insistence on distant reading leads to some unnecessary assumptions ("C," p. 64). It leads him to assume that the most significant feature of any particular work is its highest level form-its genre. Other high-level classifications-subgenre, narrative voice, plot type, and so on-typically follow in importance. In part because it must ignore most or all local features, distant reading, as Moretti practices it, holds by default that the most important feature of a detective novel is that it is a detective novel. ${ }^{49}$ And yet, to give but one counterexample, the most significant feature of Sheldon's In His Steps is not its novelistic form, which is fairly trivial. Its impact on subsequent literature and culture lies disproportionately in a single, short, repeated question: What would Jesus do?

Moretti acknowledges that distant reading may concern itself not only with highest-level abstractions but also with "units that are much smaller ... than the text." Clearly it is possible to develop a "comparative morphology" of smaller units-what I have been calling local

48. Franco Moretti, “Conjectures on World Literature,” New Left Review 1 (Jan.-Feb. 2000): 57, www.newleftreview.org/A2094; hereafter abbreviated "C."

49. See Moretti, “The Slaughterhouse of Literature,” MLQ 61 (Mar. 2000): 207-27. 
forms - that require one to perform "direct textual reading" after all..$^{50}$ One can, in principle, investigate the spread of a generic form or a syntactic form. But distance is a hindrance, not a help, in studying anything but the highest-level forms or the most abstract concepts. A study of modality in imitative discourse cannot, for obvious reasons, forego close attention to what critics in the old high way of criticism called words on the page. The limiting factor for such a study is not distance (in which "the text disappears") but quantity (in which texts are multiplied).

Systematic studies of local forms require not distant reading but plural reading. The term plural reading is a bit cheeky, of course, since even the most dogmatic New Critic always reads multiple texts and understands them in relation to one another. What the term suggests, however, is not reading more ("Reading 'more," Moretti recognizes, "is . . . not the solution") but rather reading less of more ("C," p. 55). It suggests that we concern ourselves less with the words on the page of a single text than with the words on myriad pages of myriad texts. Instead of reading a hundred sentences that make up a single work, we would read a hundred analogous sentences in a hundred different works. Instead of a thousand clauses strung together one after another, we would read a thousand clauses scattered throughout the entire history of a discourse.

Only when we are confronted with this plurality does a systematic study of local forms become possible. Digital texts, Jerome McGann writes, allow "separate books and documents" to "be made simultaneously present to each other" on a scale far beyond earlier technologies of the book. ${ }^{51}$ And yet the digital archive ultimately permits not only the experience of simultaneous presence but also, through that simultaneity, the experience of difference. The genealogical meaning of any particular syntactic form lies not in itself, in its own denotative sense. It exists only in the difference between forms-in their change, divergence, and variation. We could not, for instance, grasp the historical significance of subjunctive imitation by meditating on a WWJD? key chain, or teddy bear, or even Sheldon's influential novel. A syntactic form's genealogical meaning emerges only when it is

50. See Moretti, "Style, Inc. Reflections on Seven Thousand Titles (British Novels, 17401850)," Critical Inquiry 36 (Autumn 2009): 134-58 and especially the discussion of definite and indefinite articles. In Moretti's recent work the real payoff is not a graph, chart, map, tree, statistic, network, or principle component but rather, as he himself acknowledges, a formal analysis, the product of close rather than distant reading; see Moretti, "'Relatively Blunt,'” Critical Inquiry 36 (Autumn 2009): 174.

51. Jerome McGann, Radiant Textuality: Literature after the World Wide Web (New York, 2001), p. 57. 
made simultaneously present alongside a plurality of other-and, if only ideally, all other-forms. In scope and scale, this way of approaching texts is undoubtedly alien to our traditional reading practices. But the digital archive, and the plurality it makes possible, returns us from the subjunctive to the indicative (albeit in the future tense) to ask a simple question that cannot find its answer in any single extant model or pattern: how will we read? 
